\title{
INTEGRATION OF MULTIPLE INTELLIGENCE THEORY IN THE TEACHING AND LEARNING OF MORAL EDUCATION IN MALAYSIA : A CRITICAL ANALYSIS
}

\author{
Nadarajan Thambu ${ }^{1}, \mathbf{P h D}$ \\ Associate Professor, Sultan Idris Education University, Malaysia
}

\author{
Ganesan Shanmugavelu ${ }^{2}, \mathbf{P h D}$ \\ Senior Lecturer, Institute of Teacher Education Ipoh Campus, Malaysia
}

Manimaran Vadivelu ${ }^{3}$

Senior Lecturer, Institute of Teacher Education Ipoh Campus, Malaysia

Latifah A.Jamil ${ }^{4}$

Senior Lecturer, Institute of Teacher Education Ipoh Campus, Malaysia

Kanaisan Kanapathy ${ }^{5}$

Senior Lecturer, Institute of Teacher Education Ipoh Campus, Malaysia

Article DOI: $\underline{\text { https://doi.org/10.36713/epra5192 }}$

\begin{abstract}
The purpose of this study is to analyze the advantages and needs of integrating various intelligence theories in the process of teaching and learning Moral Education in a more practical way. Smart individuals become human capital for the economic and social development of the country. However, efforts to highlight or expose the various intelligence available to students are still not given much attention by teachers. Identifying various aspects of student intelligence is still a challenge for teachers who implement the teaching and facilitation process in the Moral Education classroom. Moral Education teachers face problems to help students reach their maximum potential because of the unique and varied learning needs of students. In this regard, the theory of multiple intelligences is thought to be able to be a theoretical framework to define, understand, develop and assess the various intelligences that students have. This study uses a qualitative approach with text analysis design and document review. Therefore, this paper is structured into three parts. The first part is a discussion of the Moral Education curriculum in Malaysia, and issues in teaching pedagogy. The second part is a discussion of the theory of multiple intelligences and the Flow theory that supports it and the third part is the integration of the theory of multiple intelligences in the Daily Teaching Plan for one unit of teaching in the Moral Education class. This paper demonstrates the importance of the concept of integrating the theory of multiple intelligences in the teaching and learning of Moral Education. This article also proposes a framework for the preparation of Daily Teaching Plan for a teaching unit as a guide for Moral Education teachers.
\end{abstract}

KEYWORDS : Moral Education, Multiple Intelligences, Teaching, Learning, Integration, Flow Model 


\section{EPRA International Journal of Research and Development (IJRD)}

\section{INTRODUCTION}

The term intelligence generally refers to knowledge, creativity, wisdom, ability or mental ability to think (Ikhsan Othman \& Rohizani Yakup, 2010). The mental ability to think includes the ability to analyze, reasoning, solve problems, be able to think about abstract elements, understand a concept or idea, be able to use language and be able to learn (Kamarudin $\mathrm{Hj}$. Husin \& Siti Hajar $\mathrm{Hj}$. Abdul Aziz , 2011). It turns out that the term intelligence is synonymous with the cognitive ability or IQ possessed by the individual. According to Stenberg and Slater (1982), intelligence is an action or thought that is purposeful or adaptive. Intelligence is said to help us to survive, see information, acquire knowledge and skills, generate ideas to solve problems, communicate and help us make wise decisions (Jasmine, 1996).

The goal of the new Moral Education curriculum in the Secondary School Standard Curriculum (KSSM) is to enable all students to achieve the maximum potential of their intelligence (Nurulwahida \& Ahmad Azman, 2014). According to Gardner (1983), intelligence is "the ability to solve problems or fashion products that are of consequence in a particular cultural setting or community" (p.15). He suggested that individuals differ in their intellectual strengths and weaknesses, and that a teacher or coach, in order to optimize the teaching and learning environment, should be able to identify and teach these abilities using a variety of highly correlated activities (Gardner, 1999). In other words, teachers or coaches should teach with a variety of teaching strategies that encompass the abilities of different students, and providing many varied experiences is an important component to help students educated individuals ( KBSM Moral Education Syllabus, 2000 ).

\section{MORAL EDUCATION IN MALAYSIA}

Moral Education is a program that educates students to become moral or virtuous human beings by emphasizing the developmental aspects of moral thinking, moral feelings and moral behavior (Nadarajan \& Ganesan, 2016). Moral education in secondary schools focuses on efforts to cultivate the spiritual strength and morality of students through the appreciation and practice of the noble values of Malaysian society found in the religions, traditions and customs of various races in Malaysia (KBSM Moral Education Syllabus, 2000). Thus, students can build a life guide that allows them to become human beings with high moral value. This allows them to be morally and socially responsible individuals for all decisions and actions taken. Several key principles have been identified as a guide in producing a comprehensive human being in terms of physical, intellectual, emotional, spiritual and social (KBSM Moral Education Syllabus , 2000).

The Moral Education Program in Malaysia aims to produce people with noble values who have a positive character. Students should have a positive character consisting of the dimensions of thinking, reasoning, intelligence, feelings and moral actions (KBSM Form Four Moral Education Syllabus Description, 2004). All of these elements are necessary for the achievement of an individual's level of moral maturity. Clearly, morality cannot be assessed from the aspect of cognitive achievement alone. Morality should also involve the development of various intelligences that can be transformed through individual behavior (Nadarajan et al, 2020 ). Therefore, teaching that stimulates the growth of student intelligence is necessary to produce students who have feelings and moral sensitivity. The development of various intelligences that are able to touch the consciousness of the individual's conscience, can address the widespread social symptoms among students (Nadarajan et al, 2020).

\section{The Moral Education Curriculum in} Malaysia enables students to

1. Understand and appreciate the values needed to be virtuous.

2. Recognize and accept the importance of harmony between humans and the environment and strive towards maintaining it.

3. Enhance understanding and cooperation to maintain peace and harmony living in a democratic Malaysia.

4. Develop mature thinking based on moral and spiritual values in moral decision making and problem solving.

5. Have a commitment to practice moral behavior in a fair and altruistic manner in line with the noble values of Malaysian society.

In planning and implementing this curriculum, focus should be given to the development and mastery of thinking and learning skills to enable students to make decisions and solve problems rationally in facing the complex life challenges. The diversity of students' intelligence must be taken into account to strengthen and enrich their learning experience in an effort to form human beings who are sensitive to issues or problems that occur and are able to make predictions, anticipate consequences and handle them towards harmony and excellence in life ( KBSM Moral Education Syllabus, 2000) . 


\section{EPRA International Journal of Research and Development (IJRD)}

Volume: 5 | Issue: 9 | September 2020

- Peer Reviewed Journal

\section{MORAL EDUCATION TEACHING AND LEARNING PROBLEMS}

Implementing the theory of multiple intelligences in the teaching and facilitation process by Moral Education teachers has long been proposed by the Ministry of Education Malaysia ( KBSM Form Four Moral Education Syllabus Description, 2004). However, its implementation in teaching and facilitation in the classroom is still a question mark. Studies in Malaysia showed that, teaching and facilitation in Moral Education classes still leads to traditional intelligence, namely language intelligence and logicmathematical intelligence (Liau, Liau, Teoh \& Liau, 2003; Ucak, Bag, \& Usak, 2006). Thus, the teaching and learning process of Moral Education in the classroom becomes too exam-oriented teaching, giving priority to copying notes as well as teaching to pass the exam alone (Vishalache Balakrishnan, 2009; 2011). This is also true because the teaching process of Moral Education is now more to the role of teachers to transfer the 'know-how' knowledge and responsibility of teachers, begins and ends with the task of programming all the subject content to students (Abd. Shatar Che Abd. Rahman, 2009; Nadarajan Thambu, 2014).

In addition, many teachers chase time and rush to finish the Moral Education syllabus before the end-of-year examination (Nadarajan Thambu, 2014). They do not appreciate the diversity of students and do not plan their teaching according to all the intelligence or any specific area of intelligence available to their students. As a result, student involvement in the classroom is less encouraging. Pupils are not motivated and lazy to engage in the learning process. One-way and bland teaching of teachers makes it difficult for students to understand, remember and do not want to be actively involved such as giving ideas or opinions when teachers ask questions (Nadarajan Thambu, Noor Banu Mahadir Naidu, \& Muhammad Atiullah Othman, 2018). Accordingly, the implementation of planned actions and taking into account the level of intelligence of individuals can increase motivation as well as give them the opportunity to show their unique aspects of intelligence through activities and assignments in the classroom.

In addition, students are also unable to apply everything they learn in the Moral Education classroom when faced with problems in real life (Vishalache Balakrishnan, 2011). Pupils often skip classes, skip school and engage in vandalism (Arsaythamby Veloo \& Ng, 2014) because they are unable to master the language and logicmathematical intelligence that is the target of assessment and evaluation in exams. In the context of Malaysia, the existence of various social problems such as burglary, murder, bullying and the spread of a gangsterism culture, as well as hedonism involving students (Zainul Arifin Md. Isa, 2012) are also increasing. This scenario has caused the education authorities and parents have asked the school to review the effectiveness of the teaching and facilitation process of Moral Education (Elizabeth Jaya Joseph, 2012; Ibrahim Bajunid, 2012). Apparently, neglecting the various aspects of intelligence, leads to a waste of human resources or human capital that can generate the country's economy.

In conclusion, a teaching and facilitation strategy of Moral Education that integrates the theory of multiple intelligences is necessary for understanding and its application to polish the various intelligences of Moral Education students. In addition, the theory of multiple intelligences is also able to explore the strengths, abilities, tendencies and interests of students through activities carried out in the classroom (Yang, 2010). Mastery of various intelligences can equip the younger generation with the skills needed to compete in the job market, as well as be an enabler of overall economic development. Thus, the study of the empowerment of various intelligence theories in Moral Education is appropriate to expose students to the process of thinking, generating ideas and active involvement in learning (Gardner, 2006) as well as the mastery of various unique intelligence of a student through the process of teaching and facilitation.

\section{MULTIPLE INTELLIGENCES THEORY}

The theory of multiple intelligences was pioneered by Howard Gardner in 1983. According to Gardner (1983; 1999), in the context of education, schools focus only on linguistic intelligence and logic-mathematical intelligence. Schools fail to identify other abilities that students have; which is also an award that should be celebrated by all. He stated that students who have other abilities besides language and logic-mathematical intelligence, are not given attention because all this time human beings are familiar and seem to receive intelligence in the sense that it should be based on scores in IQ tests. According to Gardner (1983; 1999 ), is an overly narrow view and he has recommended nine forms of intelligence present in humans to explore the potential that exists in children and adults.

The theory of multiple intelligences has been widely applied in western countries and Europe (Ikhsan Othman \& Rohizani Yakup, 2010). Based on this theory, each individual has at least eight intelligences namely verbal-linguistic intelligence, logical-mathematical intelligence, visual-spatial intelligence, kinesthetic intelligence, musical intelligence, interpersonal intelligence, intrapersonal intelligence, and naturalist 


\section{EPRA International Journal of Research and Development (IJRD)}

Volume: 5 | Issue: 9 | September 2020

- Peer Reviewed Journal

intelligence. (Armstrong,

2003). Gardner

(2006),
1994

explains that each intelligence is separate and not interdependent with each other. Refer to Table 1.

Table 1: Howard Gardner's Multiple Intelligences

\begin{tabular}{|l|l|}
\hline \multicolumn{1}{|c|}{ Multiple Intelligences } & \multicolumn{1}{|c|}{ Description } \\
\hline $\begin{array}{l}\text { Verbal-linguistic } \\
\text { intelligence }\end{array}$ & $\begin{array}{l}\text { Word-smart - ability to use words effectively, and to use abstract } \\
\text { reasoning, symbolic thinking and conceptual patterning }\end{array}$ \\
\hline $\begin{array}{l}\text { Logical-mathematical } \\
\text { intelligence }\end{array}$ & Number-smart - the capacity to use numbers effectively and to reason well \\
\hline Musical intelligence & $\begin{array}{l}\text { Music-smart - capacities such as the recognition of and use of rhythmic } \\
\text { and tonal patterns and sensitivity to sounds from the } \\
\text { environment, the human voice, and musical instruments }\end{array}$ \\
\hline Spatial intelligence & $\begin{array}{l}\text { Picture-smart - the ability to perceive the visual-spatial world accurately } \\
\text { and to perform } \\
\text { transformations based on those perceptions }\end{array}$ \\
\hline $\begin{array}{l}\text { Bodily-kinaesthetic } \\
\text { intelligence }\end{array}$ & $\begin{array}{l}\text { Body-smart - the ability to use the body to express emotion, to play a } \\
\text { game, and to create a new product }\end{array}$ \\
\hline Intrapersonal intelligence & $\begin{array}{l}\text { Self-smart - self-knowledge and the ability to act adaptively on the basis of } \\
\text { this knowledge }\end{array}$ \\
\hline Interpersonal intelligence & $\begin{array}{l}\text { People-smart - the ability to work cooperatively with others in a small } \\
\text { group, as well as the ability to communicate verbally and nonverbally with } \\
\text { other people }\end{array}$ \\
\hline Naturalistic intelligence & $\begin{array}{l}\text { Nature-smart - the ability to recognize patterns in nature and classify } \\
\text { objects; the mastery of taxonomy; sensitivity to features of the natural } \\
\text { world, and an understanding of different species }\end{array}$ \\
\hline
\end{tabular}

(Adapted from Gardner 1999; Gouws 2007)

According to Gardner (2006), each individual has eight intelligences but each intelligence is at a different level based on individual strengths and skills. All intelligence disclosed by Gardner can be developed through education, experience and environment (Armstrong, 1994; Campbell, Campbell \& Dickenson, 1996). Clearly, Gardner's theory has provided a framework and hope for a transformation or change (metamorphosis) of education at all levels of learning. All intelligence is interrelated and one intelligence can be used to enhance the other intelligence. Personal background is an important factor in shaping knowledge, beliefs and skills in all intelligences (Kagan \& Kagan, 1998).

\section{FLOW THEORY}

In this theory, Flow is a situation when a person becomes very 'immersed' in carrying out activities and skill levels appropriate to the challenges faced. Flow is an internal state in the form of pleasure that involves a person's positive experience, so that the person can control himself to stay focused while doing something. The next question in the field of positive psychology is, how to create a Flow? Flow becomes attractive for positive psychology as it relates to performance, goal orientation, creativity, attention, and emotion. This concept is increasingly popular among researchers such as Ryan and Deci (2000), who are interested in the intrinsic flow of motivation

Seligman (2002), the father of positive psychology, in his book Authentic Happiness: Using the New Positive Psychology to Realize Your Potential for Lasting Fulfillment, explains that Flow is considered an important part of enhancing human experience to live a meaningful life, where we use our virtue and strength for 'something much greater'. While Flow described by Csikszentmihalyi ( 1998 ) is based on his many years of research that begins with the creative process. The model popularized by Csikszentmihalyi ( 1998 ) is known as the Flow Model (Figure 1). In this model there are eight different zones. The main parts that need to be considered here, as we have mentioned, can be seen in the graphic axis of the book by Csikszentmihalyi ( 1998 ) entitled Finding Flow: The psychology of engagement with everyday life. 


\section{EPRA International Journal of Research and Development (IJRD)}

Volume: 5 | Issue: 9 | September 2020

- Peer Reviewed Journal

\section{FLOW MODEL}

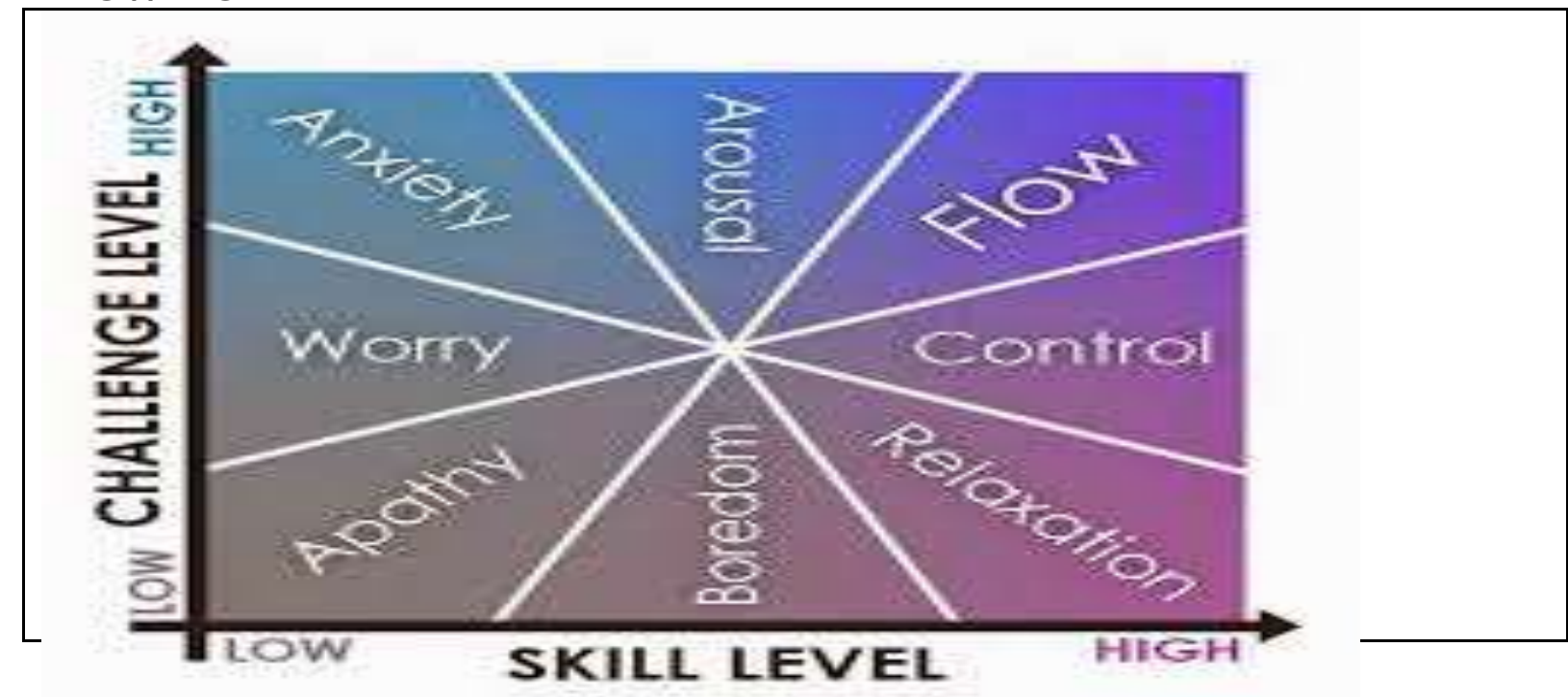

Flow conditions include a strong enough passion and interest to perform a task, leading to a pleasant experience, a person consciously and actively using all his abilities to fulfill the task. The balance that occurs between one's skills and task challenges is often seen as a prerequisite for creating Flow conditions. Bakker ( 2007 ) in his research on Flow, describes three characteristics of Flow. Arn old describes the three characteristics of Flow as follows: absorvation, enjoyment, intrinsic motivation. Absorvation is the ability to focus on what is being done. Enjoyment is comfort while on duty. Intrinsic Motivation is a driving factor or more commonly referred to as an internal drive. If a person experiences a Flow condition, the person feels able to complete a particular task.

Therefore, the concept of Flow theory (Csikszentmihalyi, 1990), must be understood before we understand the theory of intelligence and its relation to an activity in the process of teaching and facilitation in the classroom. According to Csikszentmihalyi (1990), Flow theory refers to the zone of pleasure and enjoyment that exists between boredom and anxiety based on the level of skill of the participant and the level of challenge of an assignment. For example, participants with low skill levels in challenging activities may feel anxious, while participants who are highly skilled in very simple tasks may experience boredom. Clearly, classroom activities provide opportunities for students to highlight their own areas of intelligence. Activities in this teaching and facilitation process help students to identify and use the various areas of intelligence they possess .

\section{LITERATURE REVIEW}

The eight senses of the individual function in a unique way within each individual. There are individuals who have a high level of intelligence in almost all nine senses and there are those who do not. Most humans are intermediate in some types of intelligence and less formed in one or two types of intelligence. Intelligence works together in complex ways. There is no intelligence that works alone. All intelligences interact and are related to each other (Jamal@ Nordin Yunus et al., 2011). Intelligence can be developed. Gardner $(1983 ; 1999)$ states that each individual has the ability to develop all his intelligence with appropriate encouragement, enrichment and teaching.

Studies on the use of multiple intelligences have been conducted in various fields and subjects. Among them are Vincent, Ross and Al Williams (2002), have applied the theory of multiple intelligences in the field of International Business. Lewicki (2002), on the other hand, uses the theory of multiple intelligences in the field of musical theater, while Mitchell and Kernodle (2004), on the other hand, use the theory of multiple intelligences to teach tennis. Similarly, multiple intelligence theories are used in the teaching of mathematics (Gouws \& Dicker, 2011), in the teaching of drama (Akyol, 2018; Guss, 2005), dance (Warburton, 2003) as well as integrated in technology of teaching. (McCoog, 2007).

Gouws (2007), in his study stated that the theory of multiple intelligences can create opportunities to develop students' ability to think independently, creatively, and critically. Students not only learn to solve problems, imagine new ideas or products, but also they are able to develop their own strengths. One key to simplifying the process of recognizing one's 


\section{EPRA International Journal of Research and Development (IJRD)}

own intelligence is through the teaching and facilitation experience that takes place in the classroom. Multiple intelligence theories can be applied by integrating all intelligence into daily lesson planning to be implemented practically.

In addition, Gunduz and Ozean (2016), have made a study on preschool children. The objective of their study was to investigate the effectiveness of the constructivism curriculum through storytelling methods on the achievement of various preschool children's intelligence. Studies conducted in mixed mode experimental design, showed that, story telling methods provide children with the opportunity to achieve the highest levels of achievement or intelligence in linguistic verbal intelligence, naturalistic abilities, visual-spatial abilities, and body-kinesthetic abilities. This proves that classroom activities such as storytelling activities can develop a variety of individual intelligence.

Multiple intelligence theories are also used to study the relationship of intelligence with individual career choices. Johnson and White (2002), conducted a survey study of 263 students of the Criminal Justice course on the relationship of career choice with their intelligence. Data analysis shows that Criminal Justice course students have intrapersonal intelligence (self smart). In addition, the results of the study also show that there is a significant difference between career choice and individual intelligence. However, according to Johnson and White (2002), this study has helped students to identify the strengths and weaknesses in the aspects of intelligence they possess.

Hopper and Hurry (2000), on the other hand, have studied the effectiveness and potential of various intelligence theories in the teaching and facilitation process of primary and secondary school teachers. Teachers are asked to provide various activities to students based on the theoretical framework of various intelligences. They also provide different activities for each intelligence, namely focusing on intelligence specific to a particular teaching as well as integrating multiple intelligences in all teaching topics. The results show that various intelligence theories increase awareness of the learning process among teachers. In addition, it has also increased emphasis on the individual learning process as well as stimulating active learning among teachers.

\section{INTEGRATION OF VARIOUS INTELLIGENCE IN TEACHING}

Each intelligence is different according to the student. Applying this theory as a framework in the teaching of Moral Education in the classroom is not an easy task, because educators need to be creative in their teaching. Subsequent discussions provide suggestions for the application of multiple intelligences in teaching. Literature Review offer various strategies on how to apply various intelligence theories in the classroom, and how teachers can stimulate students' intelligence through teaching and learning activities.

Teachers can integrate multiple intelligence theories into each step of Moral Education teaching in the classroom. In the induction set section, (teaching about environmental values ) for example, teachers can project words related to moral concepts through power-point

presentation. Immanual Kant (1964) words such as " the death of dogma is the birth of morality", can be displayed for discussion. The teacher can have question and answer session with the students and ask the students to explain the meaning of the words and their feelings towards the words. This discussion can uncover the attitudes and personalities of students about their morality, value system and awareness of harmony between humans and the environment. It can also polish their intrapersonal ( self smart) intelligence .

In addition, in the teaching development section, activities such as video screenings can polish their naturalistic (nature smart) intelligence. For example, teachers can show videos while discussing environmental issues and the importance of forests to ecosystem balance. Videos about the richness of fauna and flora as well as the diversity of biodiversity in the Tropical Rainforest, can enhance the environment. Discussion and appreciation of the greenery of the environment can also apply the value of loving and appreciating the environment, in addition to applying the attitude that people need to have towards the treasures of nature. Awareness of the importance of forests to humans and their inhabitants is also a catalyst for naturalist intelligence.

In the meantime, activities such as role play and simulation can form interpersonal intelligence ( people smart). Teachers can ask the class to form several groups. Each group can be asked to play a role and perform a simulation to show ways to preserve, conserve and maintain the balance of the ecosystem. Each member of the group can play a role as a teacher, counselor, forest management officer, social worker, NGO member and religious figure, to show ways to preserve and conserve the forest from the point of view of the character or figure 'played' by them. The forest conservation strategy put forward by each figure is able to highlight their interpersonal intelligence.

In addition, activities such as acting and forum theater can polish their kinesthetic intelligence ( bodily smart). Educators can provide a situation that has a conflict or moral dilemma for students to 


\section{EPRA International Journal of Research and Development (IJRD)}

Volume: 5 | Issue: 9 | September 2020

- Peer Reviewed Journal

act out. Teachers can provide the following situations:

"The forest area behind your house will be developed by some residents to be used as an agricultural area. This action was stopped by a group of members from the Nature Lovers Organization who went on strike while carrying banners. You as one of the residents are asked to give an opinion to defend the forest area from being destroyed.

At the same time, some residents are trying to defend their claim that forests should be destroyed for the sake of agriculture. In that dialogue you need to insert the reason and rationale of your claim to preserve the forest. Act out the situation".

The ability of individuals to deliver messages through acting activities or forum theater can highlight their kinestatic intelligence (bodily smart). Meanwhile, music intelligence ( music smart), can be applied through the activity of creating song lyrics and singing activities. Students can be asked to create song lyrics related to environmental issues and sing the song solo or in groups. Students can also be given freedom of choice of words to sing. While activities such as completing an essay or mind map on the "Global Warming Phenomenon" can generate Verbal-linguistic( word smart) intelligence .

\section{DAILY LESSON PLAN}

It is the responsibility of educators to nurture students and help them develop their own intelligence. Each intelligence has the potential of every student and if lesson planning is designed to challenge different intelligences, students will be exposed to more than one type of learning, which increases the likelihood of successful achievement of desired outcomes. Lesson planning should include activities to combine as many different intelligences as possible. Educators need to plan a Daily Lesson Plan for each lesson they deliver. In planning lessons to incorporate multiple intelligences, educators can use the means or concepts as shown in Figure 2.

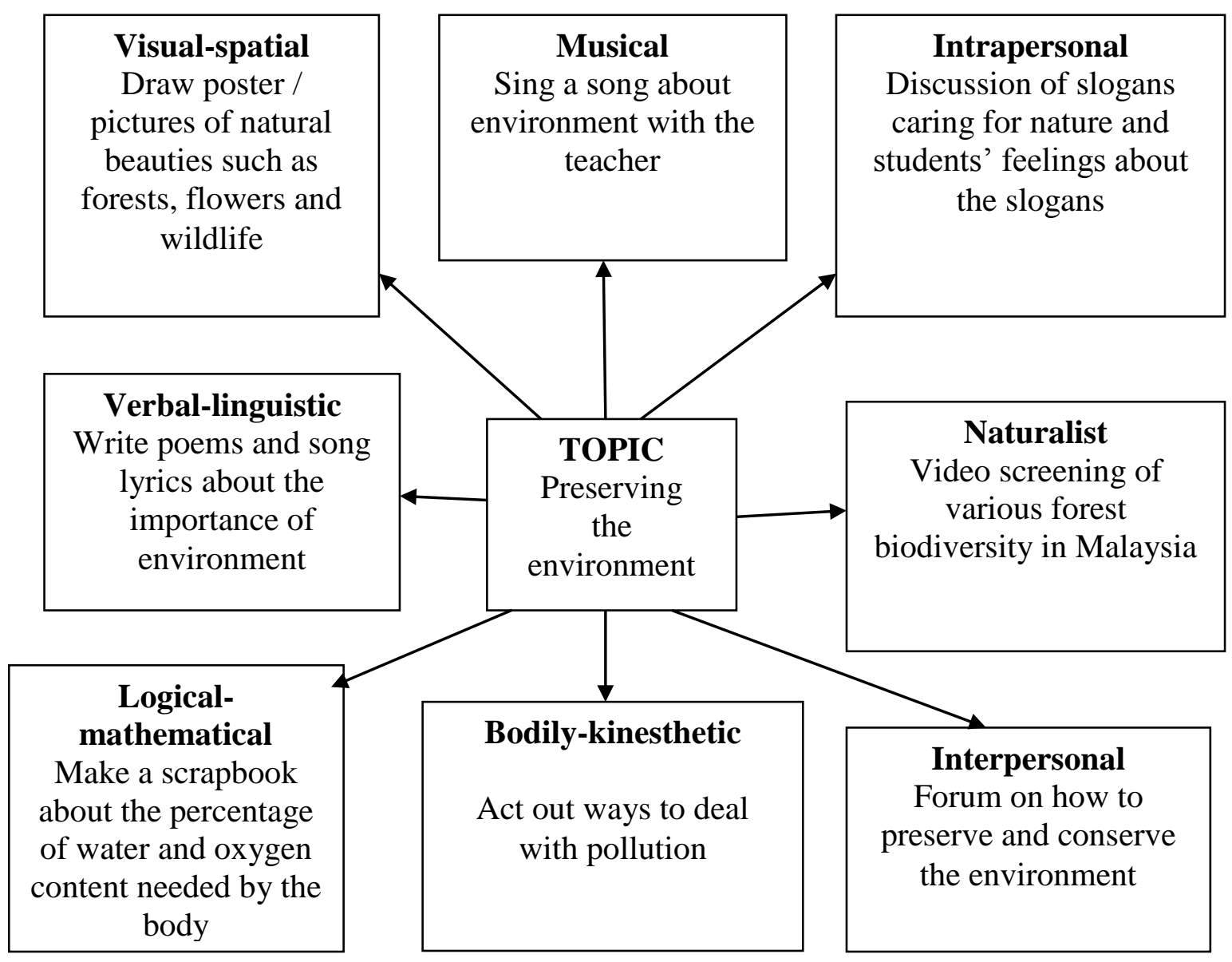

Figure 2: Incorporate Multiple Intelligences in Lesson Plan 


\section{EPRA International Journal of Research and Development (IJRD)}

\section{CONCLUSION}

One of the objectives of the Malaysian Education Development Plan 2013-2025 is to produce Malaysians who appreciate values, in addition to the application of imigination, talent, appreciation, creativity and innovation in work. This effort can be realized by integrating various intelligence aspects in the teaching and learning process of Moral Education in Schools. The wave of transformation of national education requires teachers and educational institutions to produce individuals who have cognitive skills such as aplication, reasoning and various intelligences, as these elements influence student behavior in facing the challenges of globalization and in preparation for the needs of the 21 st century.

\section{ACKNOWLEDGEMENTS}

We would like to thank the Research Management \& Innovation Center (RMIC), Universiti Pendidikan Sultan Idris and the Ministry of Education [No File: 2018-0131-106-01] for the financial assistance provided to carry out this study

\section{REFERENCES}

1. Abdul Shatar bin Che Abdul Rahman. (2009). Pengetahuan kandungan dan pedagogi guru Pendidikan Moral tingkatan empat di sebuah sekolah. Tesis doktor falsafah yang tidak diterbitkan, Universiti Malaya, Kuala Lumpur.

2. Akyol, A.K. (2018). Examination of the effect of drama education on multiple intelligence areas of children. Early Child Development and Care, 188(2), 157-167.

3. https://doi.org/10.1080/03004430.2016.1207635

4. Armstrong, T. 1994. Multiple Intelligences in the classroom. Alexandria: ASCD.

5. Arsaythamby Veloo., \& Ng, C. K. (2014). Jenis amaran dan faktor ponteng sekolah dalam kalanganpelajarsekolah menengah di Sabah. Asia Pacific Journal of Educators and Education, 29, 125- 139.

6. Bakker, A. B. (2007). The work-related flow inventory: Construction and initial validation of the WOLF. Journal of Vocational Behavior, 72, 400-414.

7. Campbell, L., Campbell, B., \& Dickenson, D. (1996). Teaching and learning through multiple intelligences. Needham Heights: Allyn \& Bacon.

8. Csikszentmihalyi, M. (1990). Flow: The psychology of optimal experience. New York, NY: Harper Perenial.

9. Csikszentmihalyi, M. (1998). Finding Flow: The psychology of engagement with everyday life. New York: Basic Books.

10. Elizabeth Jaya Joseph. (2012, Jun 5). High in education, low in virtue. New Straits Times, $p$. 19.

11. Gardner, H. (1983). Frames of mind: The theory of multiple intelligences. New York: Basic Books.
12. Gardner, H. (1999). Intelligences reframed: Multiple Intelligences for the 21st century. New York: Basic Books..

13. Gardner, H. (2006). Multiple intelligences:New horizons. New York: Basic Books.

14. Gouws, F.E. (2007). Teaching and learning through multiple intelligences in the outcomesbasededucationclassroom. Africa Education Review, 4(2), 60-74.

15. https://doi.org/10.1080/18146620701652705

16. Gouws, E., \& Dicker, A-M. (2011). Teaching mathematics that addresses learners' multiple intelligences. Africa Education Review, 8(3), 568-587.

17. https://doi.org/10.1080/18146627.2011.618721

18. Gunduz, N., \& Ozcan, D. (2016). The development of Multiple Intelligence with storytelling. InternationalJournal of Educational Sciences, 15 (1-2), 242-251.

19. https://doi.org/10.1080/09751122.2016.1189053 3

20. Guss, F.G. (2005). Dramatic playing beyond the theory of multiple intelligences. Research in Drama Education, 10(1), 43-54.

21. https://doi.org/10.1080/13569780500053155

22. Hopper, B., \& Hurry, P. (2000). Learning the MI way: The effects on students' learning of using the theory of multiple intelligences. Pastoral Care in Education, 18(4), 26-32.

23. Ibrahim Bajunid. (2012, Jun 22). Education reforms that are ideal: Matters that need attention: Consensus building crucial to charting our future. New Straits Times, p. 18.

24. Ikhsan Othman, \& Rohizani Yakup. (2010). Aplikasi teori kecerdasan pelbagai dalam pelaksanaan kurikulum. Asia Pacific Journal of Educators and Education, Vol. 25, 21-32.

25. Jamal @ Nordin Yunus, Khuan Wai Bing, Marinah Awang, Suzyanty Mohd Shokory \& Zuraidah Zainol (2011). Pemikiran Kritis dan Kreatif. Petaling Jaya, Selangor: Pearson Malaysia Sdn. Bhd.

26. Jasmine, J. (1996). Teaching with multiple intelligence. Westminster: Teacher Created Materials.

27. Johnson, $K$ \& White, J.T. (2002). The use of multiple intelligences in criminal justice education. Journal of Criminal Justice Education, $\quad$ 13(2), 369-386. https://doi.org/10.1080/10511250200085531

28. Kagan, S. \& Kagan, M. (1998). Multiple Intelligences. San Clemente: Kagan Coperating Learning.

29. Kamarudin Hj. Husin \& Siti Hajar Hj. Abdul Aziz. (2011). Pedagogi: Asas Pendidikan. KualaLumpur: Kayazano Enterprise.

30. Kant, I. (1964). Groundwork on the metaphysics of morals (H. J. Paton, Terj.). New York, NY: Harper \& Row

31. Kementerian Pelajaran Malaysia. (2000). Sukatan Pelajaran Pendidikan Moral KBSM. Pusat Perkembangan Kurikulum. Kuala Lumpur: Dewan Bahasa dan Pustaka. 


\section{EPRA International Journal of Research and Development (IJRD)}

32. Kementerian Pelajaran Malaysia. (2004). Huraian Sukatan Pelajaran Pendidikan Moral KBSMTingkatan Empat. Pusat Perkembangan Kurikulum. Kuala Lumpur: Dewan Bahasa dan Pustaka.

33. Lewicki, K. (2002). Satisfying Multiple Intelligences and diverse talents through Musical Theater.Middle School Journal, 34(2), 39-44.

34. https://doi.org/10.1080/00940771.2002.1149535 2

35. Liau, A. K., Liau, A. W. L., Teoh, G. B. S., \& Liau, M. T. L. (2003). The case for emotional literacy: The influence of emotional intelligence on problem behaviours in Malaysian secondary school students. Journal of Moral Education, 32(1), 51-66.

36. McCoog, I.J. (2007). Integrated Instruction: Multiple Intelligences and Technology. The Clearing House: A Journal of Educational Strategies, Issues and Ideas, 81(1), 25-28.

37. https://doi.org/10.3200/TCHS.81.1.25-28

38. Mitchell, $M$ \& Kernodle, M. (2004). Using Multiple Intelligences to teach tennis. Journal of PhysicalEducation, Recreation \& Dance, 75(8), 27-32.

39. https://doi.org/10.1080/07303084.2004.1060728 6

40. Nadarajan Thambu. (2014). Penggunaan Teater Forum dalam pengajaran dan pembelajaran Pendidikan Moral di sekolah menengah. Tesis doktor falsafah yang tidak diterbitkan, Universiti Malaya, Kuala Lumpur.

41. Nadarajan Thambu \& Ganesan Shanmugavelu. (2016). Unsur 'niat moral' dalam Teater Forum: Satu kajian tindakan di kelas Pendidikan Moral. Asian Education Action Research Journal (AEARJ), 5, 1-14.

42. Nadarajan Thambu, Noor Banu Mahadir Naidu, \& Muhammad Atiullah Othman. (2018). Pemerkasaan Pedagogi Kritis untuk menjana Kemahiran Berfikir Aras Tinggi(KBAT) melalui teknik Teater Forum dalam kalangan murid Pendidikan Moral di Sekolah Menengah. Monograf yang tidak diterbitkan, Universiti Pendidikan Sultan Idris, Tanjong Malim.

43. Nadarajan Thambu, Vasanthan Gurusamy, ZurainiJamil @Osman, \& Sukadari. (2020). The development of multiple intelligences in moral education class through forum theatre. Journal of Critical Reviews, 7(14), 2394-5125.

44. Ryan, R.M., \& Deci, E.L. (2000). Intrinsic and Extrinsic Motivations: Classic Definitions and New Directions. Contemporary Educational Psychology, 25, 54-67.

45. http://www.idealibrary.com doi:10.1006/ceps.1999.1020

46. Seligman, M. E. P. (2002). Authentic Happiness: Using the New Positive Psychology to Realize Your Potential for Lasting Fulfillment. New York, NY: Free Press.
47. Stanford, P. (2003). Multiple intelligences for every classroom. Intervention in school and clinic, 39, 80-85.

48. Sternberg, R. J., Slater, W. 1982. Conceptions of intelligence. In Sternberg, R. J(Ed.).Handbook of human intelligence. New York : Cambridge University.

49. Ucak, E., Bag, H., \& Usak, M. (2006). Enhancing learning through multiple intelligences in elementary science education. Journal of Baltic Science Education, 10, 61-69.

50. Vincent, A., Ross, D., \& Al Williams. (2002). Using the Multiple Intelligences Theory in International Business. Journal of Teaching in International Business, 14(1), 45-63.

51. https://doi.org/10.1300/J066v14n01 04

52. Vishalache Balakrishnan. (2009). Teaching Moral Education in Secondary schools using real-lifedilemmas. Tesis doktor falsafah yang tidak diterbitkan, Victoria University of Wellington.

53. Vishalache Balakrishnan. (2011). Real-life Dilemmas in Moral Education. Kuala Lumpur: Universiti of Malaya Press.

54. Warburton, E.C. (2003). Intelligence past, present, and possible: The theory of Multiple Intelligences in Dance Education. Journal of Dance Education, 3(1), 7-15. https://doi.org/10.1080/15290824.2003.103872 $\underline{24}$

55. Yang, H. (2010) Applications of Multiple Intelligences in Recreation Group Leadership Class. SCHOLE: A Journal of Leisure Studies and Recreation Education, 25:1, 130-134. https://doi.org/10.1080/1937156X.2010.1194966 1

56. Zainul Arifin Md. Isa. (2012, Jun 13). Grads without soft skills victims of system. New Straits Times, p. 19. 